УДК 336.5:338.2

https://doi.org/10.52058/2708-7530-2022-1(19)-375-390

Федик Мар'яна Володимирівна кандидат економічних наук, асистент кафедри аналітичної економії та міжнародної економіки, Львівський національний університет імені Івана Франка, проспект Свободи, 18, м. Львів, 79008, https://orcid.org/0000-0002-1067-6843

\title{
ФІСКАЛЬНА ПОЛІТИКА УРЯДУ УКРАЇНИ В УМОВАХ ГЛОБАЛЬНОЇ ПАНДЕМІЧНОЇ КРИЗИ
}

Анотація. Стаття містить дослідження щодо реалізації фіскальної політики уряду України в умовах глобальної пандемічної кризи. Мета дослідження - визначити проблеми здійснення фіскальної політики та напрями щодо iï вдосконалення 3 метою боротьби 3 наслідками пандемії COVID-19. Стаття розкриває актуальність проблеми через настання економічної кризи, що виникла не лише в Україні, але й в інших країнах світу. Одним із найбільш дієвих шляхів щодо їі подолання $є$ фіскальна політика. Порівняння досвіду боротьби розвинених країн 3 економічною кризою фіскальними методами 3 вітчизняним дозволяє дійти висновку про ефективність такої політики та визначити іiі слабкі місця. Зокрема, з усіх можливих напрямів реалізації фіскальної політики 3 метою боротьби 3 пандемією, Україна використала лише ті, що стосуються незначної підтримки населення, підтримки виробників фармацевтичної продукції, однак практично не стимулювала збереження та розвиток існуючого бізнесу. У результаті це дозволило зекономити бюджетні кошти на підтримку бізнесу та домашніх господарств, однак все ж таки не здійснило позитивного впливу на відновлення економіки. Стаття містить низку рекомендацій щодо майбутньої фіскальної політики уряду України в умовах глобальної пандемічної кризи та виходу з неї. Визначено, що фіскальна політика держави має спрямовуватися не лише на соціальне забезпечення, але й на інвестиційний розвиток. Зокрема, доцільно залучати безробітних людей до різних будівельних проєктів державного значення, а також вкладати кошти в медичне обладнання, що в результаті дозволить підвищити якість медичних послуг та стандарти життя населення.

Запропоновано основні напрями фіскальної політики уряду після подолання глобальної пандемічної кризи, а саме: інвестування у сфери розвитку людського капіталу з метою підвищення освітнього рівня населення та покращення його здоров'я; спрямування факторів праці та капіталу на нові галузі економіки, котрі отримали поштовх для розвитку під час пандемії; посилення системи соціального захисту населення 3 метою запобігання бідності та зростання нерівності; здійснення податкових реформ, націлених на збільшення оподаткування надприбуткових підприємств та бізнесів. 
Ключові слова: фіскальна політика, пандемія COVID-19, державний борг, податкове стимулювання.

Fedyk Mariana Volodymyrivna Ph.D. in Economics, Assistant of the Department of Analytical Economy and International Economics, Ivan Franko National University of Lviv, Prospekt Svobody, 18, Lviv, 79008, https://orcid.org/0000-0002-1067-6843

\title{
FISCAL POLICY OF UKRAINE'S GOVERNMENT WITHIN THE CONDITION OF THE GLOBAL PANDEMIC CRISIS
}

\begin{abstract}
The academic paper contains the research on the implementation of the fiscal policy of Ukraine's government within the conditions of the global pandemic crisis. The purpose of the research lies in identifying the issues of fiscal policy implementation and directions for its improvement in order to combat the consequences of the COVID-19 pandemic. The academic paper reveals the urgency of the problem due to the economic crisis that has arisen not only in Ukraine but also in other countries. Fiscal policy is one of the most effective ways to overcome the crisis. Comparing the experience of combating the economic crisis of advanced countries with the domestic one by applying fiscal methods makes it possible to conclude about the effectiveness of such policy, as well as identify its weaknesses.
\end{abstract} In particular, of all possible areas of fiscal policy implementation in order to combat the pandemic, Ukraine has used only those related to insignificant support of the population, support for pharmaceutical manufacturers; however, it did not stimulate the preservation and development of existing business. As a result, this made it possible to save budget funds to support businesses and households, but did not have a positive impact on the economic recovery. The academic paper contains a number of recommendations on the future fiscal policy of Ukraine's government in the context of the global pandemic crisis and overcoming it. It has been determined that the fiscal policy of the state should be aimed not only at social security, but also at investment development. In particular, it is advisable to involve unemployed people in various construction projects of national importance, as well as to invest in medical equipment, which in turn will improve the quality of medical services and living standards.

The main directions of the government's fiscal policy after overcoming the global pandemic crisis have been proposed, namely: investing in the development of human capital in order to increase the educational level of the population and improve health; directing labour and capital factors to new sectors of the economy that have received an impetus for development during the pandemic; strengthening the social protection system in order to prevent poverty and increase inequality; implementation of tax reforms aimed at increasing the taxation of profitable enterprises and businesses.

Keywords: fiscal policy, COVID-19 pandemic, state debt, tax incentives. 
Постановка проблеми. Негативний вплив пандемії COVID-19 відчула не лише Україна, але й увесь світ. Практично в кожній країні відбулося скорочення обсягів виробництва та зниження ділової активності бізнесу, зменшення інвестиційного попиту, доходів підприємств та населення. Відповідно до прогнозів Світового банку [1], фінансово-економічна криза вплинула на Україну та інші країни через такі чинники: 1) зменшення рівня доходів та споживання через впровадження обмежень ділової активності суб'єктів господарської діяльності; 2) зменшення потоку грошових коштів 3 інших країн через скорочення економічної активності та трудової міграції співвітчизників до країн $€ C$; 3) зниження цін на товари у світі, що негативно вплинуло на експорт [1].

Якщо говорити про загальний вплив пандемії на економічну активність, то на сьогодні достовірні прогнози на 2022 р. здійснювати неможливо, оскільки вони залежатимуть від масштабів нової хвилі захворювань (стрімке поширення нового штаму «Омікрон») та її тривалості, які передбачити на цей час практично неможливо [2].

Таким чином, найважливішим завданням, яке на сьогодні постає перед політикою уряду України, $є$ запровадження ефективних протиепідемічних заходів для стримання розповсюдження COVID-19, які дозволяють мінімізувати негативний його вплив на економіку України.

3 метою захисту здоров'я населення Кабінет Міністрів України вжив обмежувальні заходи, які ще в минулому році суттєво вплинули на роботу бізнесу, державних установ, а також на повсякденне життя населення [3].

Очевидно, що карантинні заходи негативно впливають на економіку та на фінанси держави, зокрема на формування бюджету. Так, станом на 2020-2021 роки відбувається суттєве відставання в бюджеті від планових показників через збільшення видатків на охорону здоров'я та соціальне забезпечення.

На сьогодні одним із дієвих інструментів, який використовується для регулювання фінансово-економічного розвитку України, є фіскальна політика [4]. Однак, необхідно зауважити, що в умовах пандемії фіскальна політика націлена на підтримку підприємництва та домогосподарств, а тому зниження обсягів бюджетних надходжень через надання суб'єктам господарювання податкових пільг поглиблюють дисбаланс у фінансово-бюджетній сфері. Цей кризовий стан характеризується такими чинниками як: 1) закриттям зовнішніх ринків збуту, що призводить до скорочення експорту. Враховуючи, що економіка України $\epsilon$ експортоорієнтованою, у багатьох ринках відбуватиметься стагнація і скорочення попиту на продукцію, що є серйозною загрозою для балансу економіки; 2) скороченням обсягів виробництва та послуг через обмеження у діяльності бізнес-структур, це особливо стосується малого i середнього бізнесу; 3) суттєвим стає зростанням бюджетного дефіциту та посилення боргових ризиків [5].

Відповідно до прогнозів українського уряду, Національного банку 
України, міжнародних організацій та інвестиційних компаній щодо розвитку економічної ситуації в умовах пандемії, можна дійти висновку, що стабілізація економічної ситуації почне відбуватися у 2022 році. Однак кожна із організацій має свої прогнози щодо періоду відновлення економік різних країн світу, проте спільною думкою $є$ те, що на сьогодні Україна потребує допомоги міжнародних фінансових структур для того, щоб забезпечити ефективне відновлення ділової активності та економіки в цілому [6]. Втім Світовий банк вважає, що перспективи економічного зростання залежать від фіскальної політики уряду, а також від реформ, які будуть націлені на підтримку експорту та інвестицій [7].

Аналіз останніх досліджень і публікацій. Останнім часом напрацювання у сфері фіскальних стимулів та політики урядів є достатньо досліджуваними як серед зарубіжних, так і вітчизняних дослідників. Зокрема, щодо зарубіжних досліджень, варто виділити найактуальніші таких авторів як Benmelech Е. та Tzur-Ilan N. [8], котрі дослідили застосування фіскальної та монетарної політики урядів під час коронавірусу у 2021 році. Вітчизняні автори Глущенко C. В. та Мельник А. I. [4] досліджували фіскальні стимули економічного розвитку у світі в умовах пандемії COVID-19. Красота О. В. та Яровой А. В. [5] вивчали шляхи відновлення макроекономічної стабільності в умовах пандемії 3 дослідженням фіскальних напрямів. Андрущенко В. Л та Тучак Т. В. [2] досліджували податково-бюджетні заходи протидії пандемії на Заході. Однак щодо висвітлення проблеми в Україні, то питання залишається недостатньо вивченим, що формує актуальність дослідження, оскільки реальної оцінки здійснення фіскальної політики уряду України, визначення проблем та напрямів її застосування не здійснювалося.

Метою дослідження $€$ визначення проблем проведеної фіскальної політики та напрямів щодо ії удосконалення з метою боротьби з наслідками пандемії COVID-19.

Виклад основного матеріалу. Усі економічні процеси характеризуються нестабільністю та чергуванням піднесення й спаду економіки, що відображається на зміні обсягів виробництва, зайнятості, інфляції та процентних ставок в країні. У свою чергу, фіскальна політика $є$ важливим інструментом макроекономічного регулювання, який у періоди економічних коливань, зокрема в період рецесії, дозволяє підтримувати економіку [4]. Саме тому актуальним та важливим $\epsilon$ аналіз зарубіжного досвіду використання фіскальних стимулів для подолання негативних наслідків фінансових криз, що відбуваються у різних країнах. У 2020 році внаслідок пандемії COVID-19 економіка всіх країн світу зазнала значних втрат, фактично світ увійшов у рецесію зі значним падінням світового ВВП, яке ще розпочалось в першому кварталі 2020 року (рис.1.) 


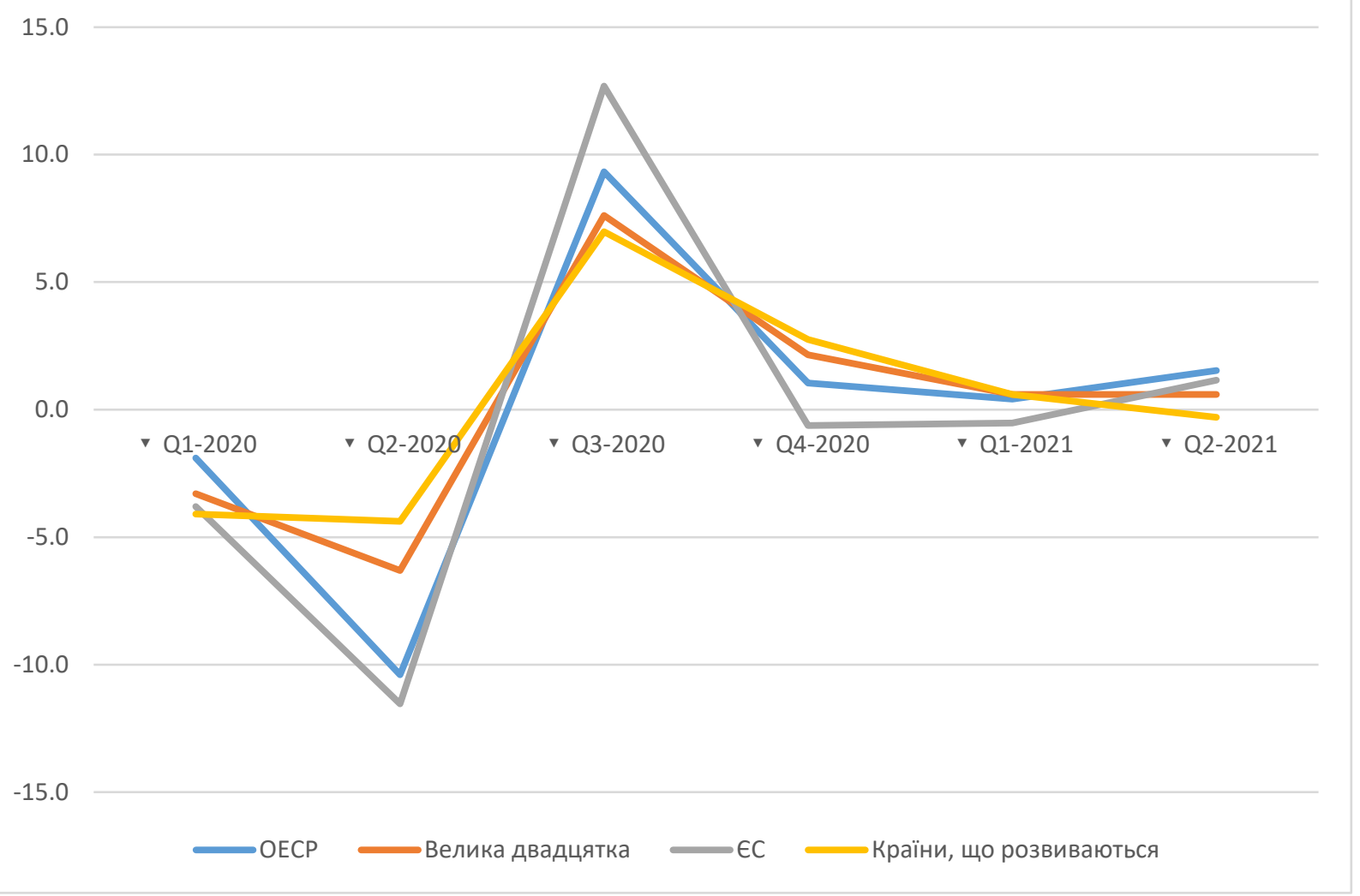

Pис. 1. Зростання ВВП впродовж 2020-2021 рр., \% до попереднього кварталу [9]

Примітка: побудовано авторами на основі даних OECD

За даними рис. 1 можна спостерігати, що максимальне падіння ВВП більшості країн світу відбулося у другому кварталі 2020 року. Жорсткі заходи, спрямовані на припинення поширення COVID-19, що були застосовані у більшості країн світу, спричинили різке падіння виробництва, зростання безробіття, падіння попиту та споживання продукції, загострилися проблеми ліквідності на підприємствах. Відповідно зменшилися розміри інвестицій та зріс дефіцит державних бюджетів й розмір світового боргу. У найбільш кризовий період максимальне падіння ВВП в середньому відбулося на $10 \%$.

Внаслідок пом'якшення обмежувальних заходів та відновлення бізнес активності, а відповідно і збільшення обсягів споживання домашніми господарствами у третьому кварталі показник ВВП зріс на $9 \%$ у порівнянні із другим кварталом. Проте це зростання не характеризувалося стабільністю, а тому в подальшому відбулося поступове сповільнення темпів зростання ВВП. Що стосується України, то найбільшого падіння ВВП зазнав у II кварталі 2020 року, де показник складав $-11,2 \%$ у порівнянні до I кварталу 2020 року. Лише у II кварталі 2021 року приріст ВВП відновився до позитивного значення (рис.2) 


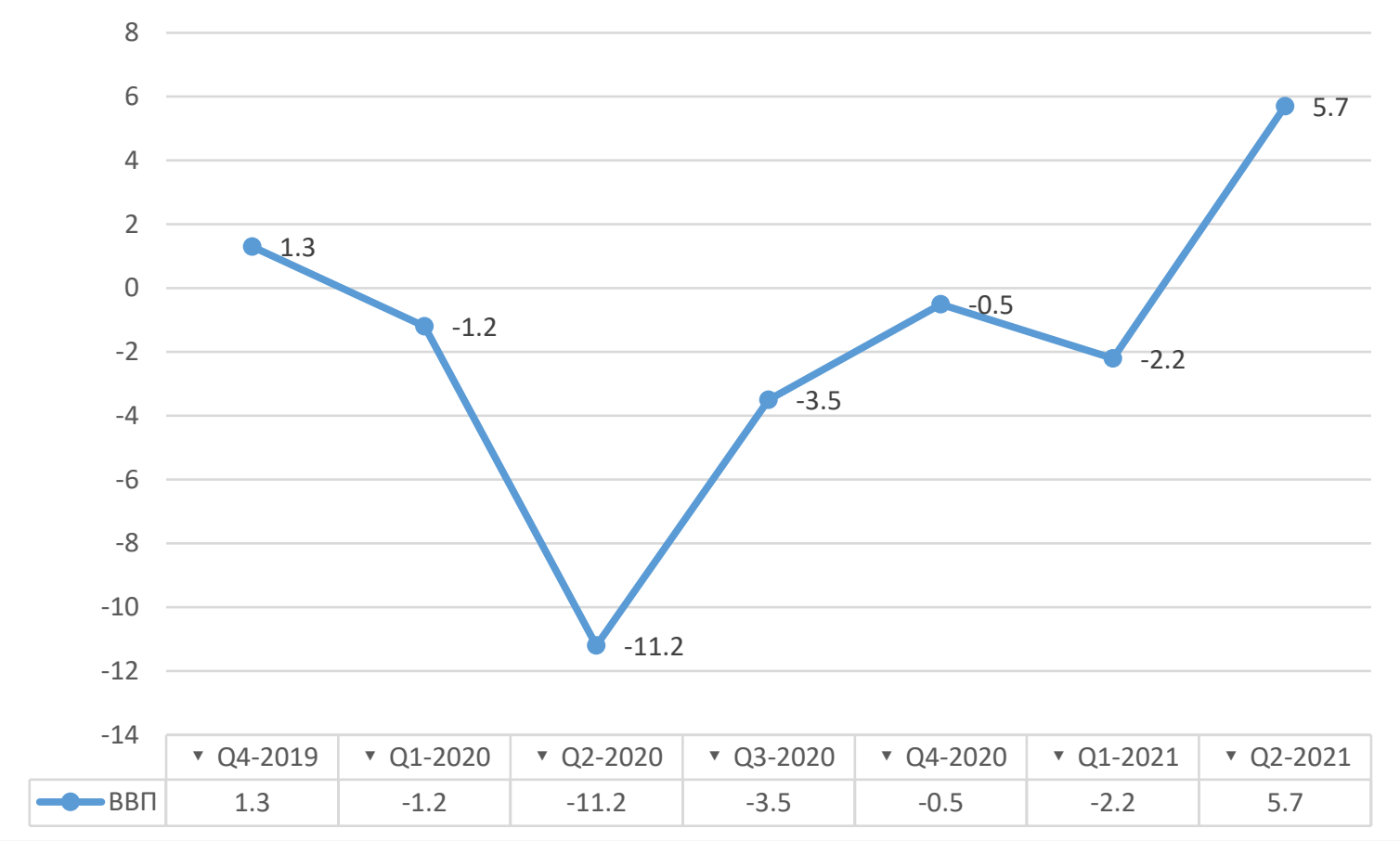

Pис. 2 Зміна реального ВВП України

(у\% до відповідного кварталу попереднього року) [10]

В умовах стрімкого падіння економічної активності практично всі країни потребували додаткового фінансування, а тому фіскальні заходи були необхідними. Для багатьох країн фіскальна політика стала занадто дорогою на фоні падіння обсягів виробництва, що спричинило стрімке зростання державного боргу [7].

Зазначимо, що найбільш результативні фіскальні стимули, які призводять до відновлення та пожвавлення економічного зростання, забезпечуються за рахунок одночасного зниження вагового показника податкових надходжень та збільшення питомої ваги первинних видатків. Враховуючи зазначене, доцільно розробляти системні заходи податкового та бюджетного стимулювання економіки для підтримки бізнесу, що страждає внаслідок карантинних обмежень. Втім наявність державного боргу не дозволяє Україні використовувати фіскальну підтримуючу політику повною мірою, а тому такі заходи повинні бути обгрунтованими та виваженими. 3 нашої точки зору, основними принципами впровадження фіскальної політики у практичну діяльність суб'єктів господарської діяльності є іï своєчасність, тимчасовість, цільове спрямування та координованість.

Рішення щодо формування фіскальної політики приймається із врахуванням певних часових обмежень, а тому ці рішення не можуть мати вагомий вплив на структуру економіки та іï динаміку [11], вони мають тимчасовий, корегуючий характер, що дозволяє дещо вирівняти спад економічної активності.

В цілому фіскальна політика уряду може проявлятися за різними напрямами. Фахівці МВФ (Fiscal Monitor: Policies for the Recovery) вважають, 
що на першій стадії розвитку епідемії та при впровадженні першого локдауну фіскальна політика повинна орієнтуватися на соціальні цілі, тобто на порятунок здоров'я та життя населення через адекватне фінансування медицини, а також надання фінансової підтримки постраждалому бізнесу та громадянам, які вимушені зупинити свою діяльність через обмежувальні карантинні заходи. Найбільш доречними інструментами фіскальної політики на цій стадії $\epsilon$ субсидії на виплату заробітної плати, а також розширення програм соціальної допомоги 3 виплат по безробіттю, надання позик та гарантій підприємцям.

На першій стадії розвитку пандемії Кабінетом Міністрів України було розроблено низку фіскальних заходів зі зниження негативного впливу пандемії. Розглянемо основні з них на рис. 3.

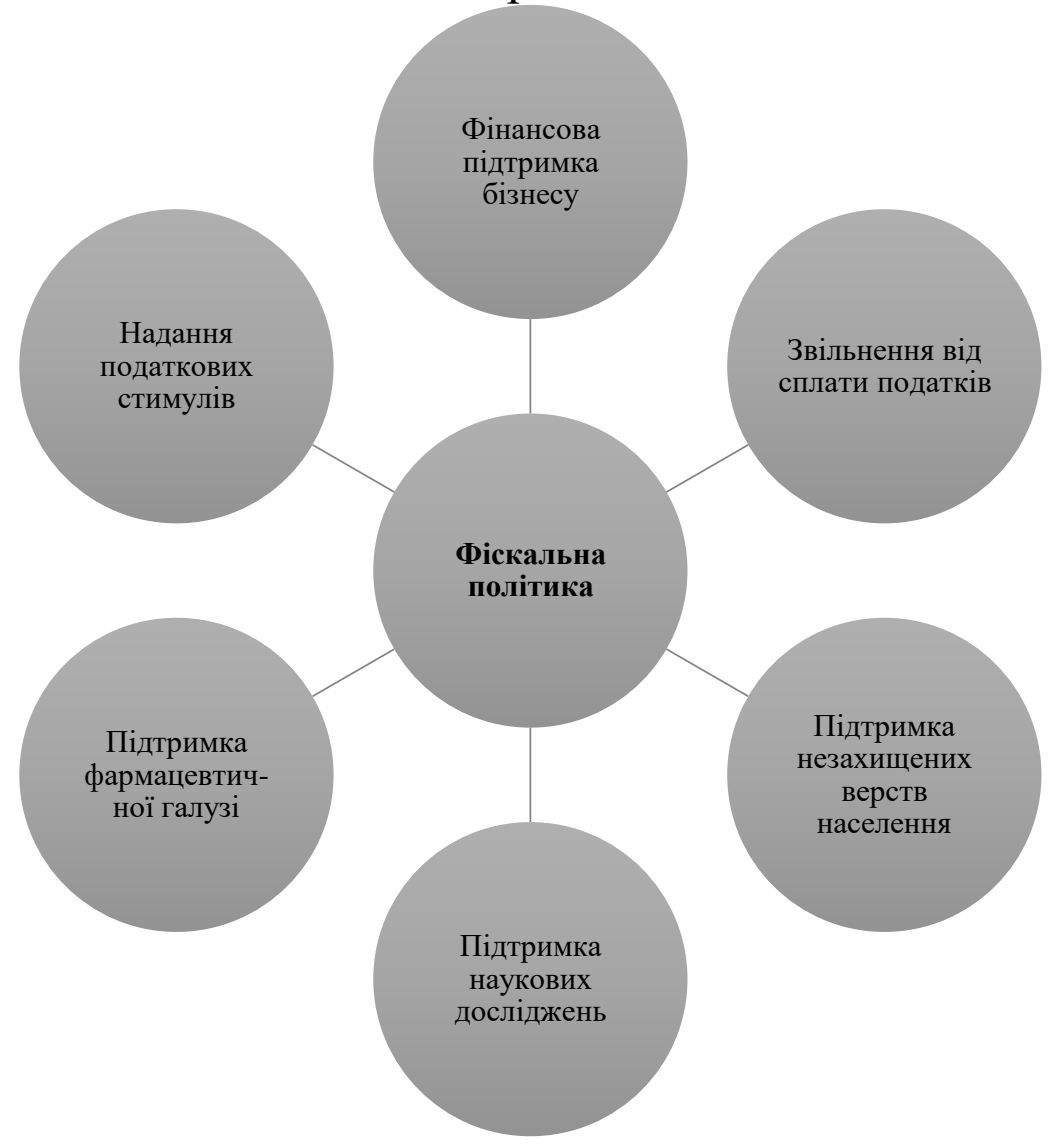

Рис. 3. Основні напрями реалізації фіскальної політики в Украӥні, котрі запобігають економічному спаду

Фінансова підтримка бізнесу полягає у безповоротній фінансовій допомозі суб'єктам економічної діяльності для збереження робочих місць. Така ініціатива повинна базуватися на чітко визначених критеріях, зокрема на виду економічної діяльності, чисельності працівників та розміру середньої заробітної плати.

Звільнення від сплати податків повинно бути організовано 3 метою зменшення податкового тягаря на найбільш незахищені верстви населення, 
тобто підприємців та представників малого бізнесу. В першу чергу це стосується звільнення від сплати єдиного соціального внеску, а також збільшення рівня податкової соціальної пільги до рівня мінімальної заробітної плати для окремих категорій населення.

Підтримка незахищених верств населення, необхідно підвищувати ефективність та адресність державної підтримки вразливих верств населення, впроваджувати додаткові соціальні послуги та послуги 3 активації до працевлаштування для працездатних одержувачів соціальної допомоги 3 метою подолання бідності, удосконалювати програми допомоги малозабезпеченим сім'ям 3 метою сприяння всебічному та справедливому охопленню вразливих верств населення. Також державна підтримка незахищених верств населення повинна полягати у наданні стабілізаційних кредитів підприємствам за рахунок державних банків 3 можливістю надання зниженої ставки за рахунок бюджетних коштів.

Підтримка наукових досліджень повинна здійснюватися шляхом збільшення цільових асигнувань бюджету під замовлення держави. Особливо це стосується досліджень, які здатні знайти напрями подолання кризи, а також 3 розроблення вакцини чи ліків проти коронавірусу. Можливе також забезпечення податкового стимулювання науково-дослідних та дослідноконструкторських розробок, зокрема таким організаціям повинна надаватися податкова знижка, яка створюється 3 метою модернізації технологій та підвищення ступеня забезпечення реального сектору економіки відповідними науковими дослідженнями.

Підтримка фармачевтичної галузі потребує застосування нульової ставки податку на додану вартість для певної групи препаратів та обладнання, які застосовуються у протоколі Міністерства охорони здоров'я щодо лікування COVID-19. Також можливо впровадження звільнення від оподаткування акцизним податком етилового спирту, який використовуються для виробництва миючих та дезінфікуючих засобів.

Надання податкових стимулів щодо виробництва енергозберігаючих технологій та транспортних засобів, які відповідають високим технологічним стандартам. Це може стосуватися застосування зниженої ставки податку на додану вартість.

Незважаючи на достатньо широке поле для реалізації фіскальної політики Уряду, по факту в Україні основними стимулюючими фіскальними заходами у 2020 році стали розширення виплат з безробіття, зменшення штрафних санкцій, фінансова підтримка пенсіонерів, медичних працівників, соціальних робітників, встановлення граничних цін на певні категорії товарів та зменшення рівня оподаткування. 
Таблиия 1.

Фіскальна політика уряду України в умовах боротьби 3 пандемісю у 2020 році [12-14]

\begin{tabular}{|c|c|c|}
\hline № & $\begin{array}{c}\text { Напрям } \\
\text { реалізації } \\
\text { фіскальних заходів }\end{array}$ & Конкретні дії Уряду України протягом 2020 року \\
\hline 1. & $\begin{array}{c}\text { Фінансова } \\
\text { підтримка бізнесу }\end{array}$ & $\begin{array}{l}\text { Фінансова підтримка фізичних осіб-підприємців, які } \\
\text { вимушені тимчпсово призупинити підприємницьку діяльність } \\
\text { внаслідок карантинних обмежень, у розмірі } 8000 \text { грн [17] }\end{array}$ \\
\hline 2. & $\begin{array}{l}\text { Звільнення від } \\
\text { сплати податків }\end{array}$ & $\begin{array}{l}\text { Звільнення від сплати єдиного соціального внеску та } \\
\text { єдиного податку для підприємців, які перебувають на } \\
\text { спрощеній системі оподаткування I групи до } 31.05 .2021 \text { року. }\end{array}$ \\
\hline 3. & $\begin{array}{l}\quad \text { Підтримка } \\
\text { незахищених верств } \\
\text { населення }\end{array}$ & $\begin{array}{l}\text { Розширення виплат із безробіття, у тому числі } 2803 \\
\text { млрд грн + 0,08 млрд грн спрямовувалися на допомогу з } \\
\text { тимчасового безробіття та } 1277 \text { млрд грн }+1199 \text { млрд грн для } \\
\text { виплати допомоги з безробіття [12]. } \\
\text { Фінансова підтримка пенсіонерів, у тому числі } \\
\text { щомісячна виплата у розмірі } 500 \text { грн пенсіонерам віком від } 80 \\
\text { років, пенсія яких не перевищує } 9205 \text { грн, також індексація } \\
\text { пенсій на } 11 \% \text { у травні } 2020 \text { року [13]. } \\
\text { Запровадження субсидій та додаткових компенсаційних } \\
\text { витрат на оплату комунальних послуг, які в середньому } \\
\text { становлять } 300 \text { грн для кожної родини; збільшення на 50\% } \\
\text { соціальних нормативів користування електроенергією, холодною, } \\
\text { гарячою водою, газом, на які розраховується субсидія [13]. } \\
\text { Підтримка медичних та соціальних працівників. } \\
\text { Соціальна та економічна підтримка домашніх господарств } \\
\text { націлена на допомогу медичним працівникам та іншим } \\
\text { працівникам, що безпосередньо зайняті на роботах з ліквідації } \\
\text { захворювання людей на коронавірус у розмірі 300\% від } \\
\text { заробітної плати; доплата до заробітної плати у розмірі 100\% } \\
\text { працівникам сфери соціального захисту населення, які } \\
\text { безпосередньо надають соціальні послуги за місцем } \\
\text { проживання отримувача соціальної послуги. }\end{array}$ \\
\hline 4. & $\begin{array}{c}\text { Підтримка } \\
\text { наукових досліджень }\end{array}$ & I \\
\hline 5. & $\begin{array}{l}\text { Підтримка } \\
\text { фармацевтичної } \\
\text { галузі }\end{array}$ & $\begin{array}{l}\text { Встановлення граничних изін на товари } \\
\text { протиепідеміологічного призначення; справляння акцизного } \\
\text { податку за ставкою } 0 \% \text { за } 1 \text { л 100\% етилового спирту, що } \\
\text { використовується для виробництва дезінфекційних засобів. }\end{array}$ \\
\hline 6. & $\begin{array}{c}\text { Надання } \\
\text { податкових стимулів }\end{array}$ & $\begin{array}{l}\text { Зменшення кількості перевірок та штрафних санкиій; } \\
\text { можллиість не заповнення книги доходів для ФОП; } \\
\text { збільшення лімітів річного обороту для ФОП І-ІІІ категорій; } \\
\text { підприємства, що займаються виготовленням спиртовмісних } \\
\text { дезінфікуючих засобів мають можливість використання } \\
\text { нульової ставки акиизного збору на спирти [13]. } \\
\text { Звільнення від оподаткування ПДВ тих товарів, що } \\
\text { ввозяться на територію України з метою боротьби з } \\
\text { COVID-19 [14]. }\end{array}$ \\
\hline
\end{tabular}


Станом на березень 2021 року на протидію COVID-19 було витрачено всіма країнами світу 19\% від світового ВВП, що становить 16 трлн дол США. Близько 10 трлн дол 3 цієї суми становлять фіскальні заходи, які дозволили здійснити податкові послаблення та бюджетні видатки; 6 трлн дол - заходи, що націлені на підтримку ліквідності компанії, у т.ч. бюджетні позики та субсидії, а також державні гарантії та вливання капіталу. Фахівці МВФ підрахували, що в цілому такі фіскальні заходи зменшили світовий ВВП у 2020 році на 2\%. Що стосується України, то за оцінками МВФ станом на березень 2021 року фіскальний пакет порятунку складав 4,3\% ВВП, у тому числі $3,5 \%$ є державними видатками та податковими послабленнями, а 0,8\% ВВП - фіскальні заходи з підтримки ліквідності підприємств України.

За даними рис. 4 можна дійти висновку, що загальна вартість фіскального пакету в Україні не є достатньою, оскільки у розвинутих країнах витрачається у 6 разів більше коштів на боротьбу із коронавірусом.

Ці розбіжності мають об'єктивні причини, оскільки українська економіка працює в умовах бюджетного дефіциту і вузького фіскального простору. Обмеженість джерел фінансування та фіскального простору зменшують силу фіскальної політики під час боротьби з COVID-19. Однак, окрім об'єктивних причин, існують й інші, до яких можна віднести неготовність державних органів надавати підтримку населенню, нераціональність використання коштів, небажання підтримувати бізнес в умовах кризи.

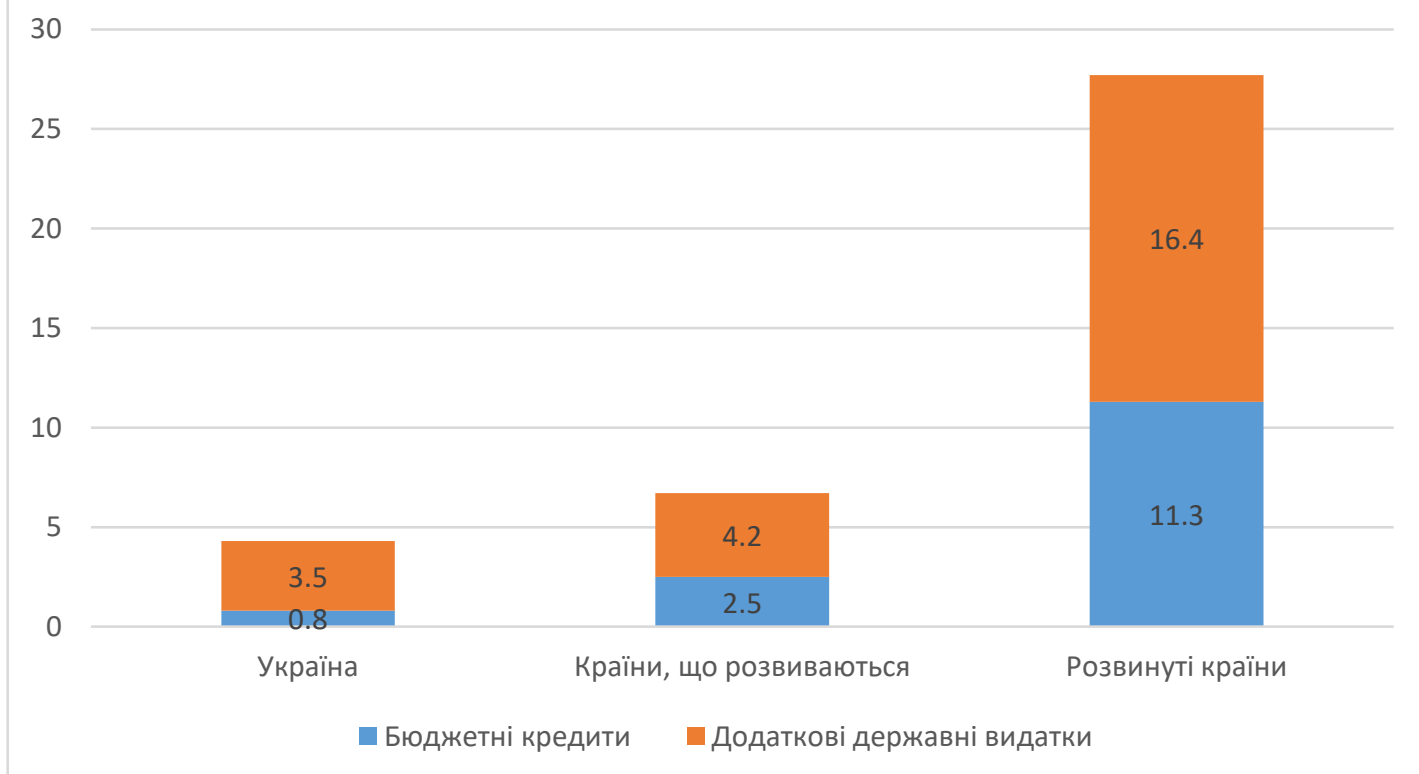

Pис. 4. Фіскальні пакети порятунку в Україні та групах країн за основними складовими станом на березень 2021 року, \% ВВП [15]

Незважаючи на рекордно низькі світові відсоткові ставки та зростання попиту на інвестиційні доходи, попит інвесторів на короткострокові державні облігації в національній валюті був невисоким. Це призвело до збільшення державного боргу не тільки в Україні, але й інших країнах світу з аналогічною 
економікою. Якщо за даними 2020 року державний борг у світі зріс на 13,6\% ВВП, і склав 97,8\% ВВП, то в Україні даний показник складає 60,7\% ВВП (рис. 5). По факту, таке значення $є$ меншим чим середні по країнах що розвиваються.

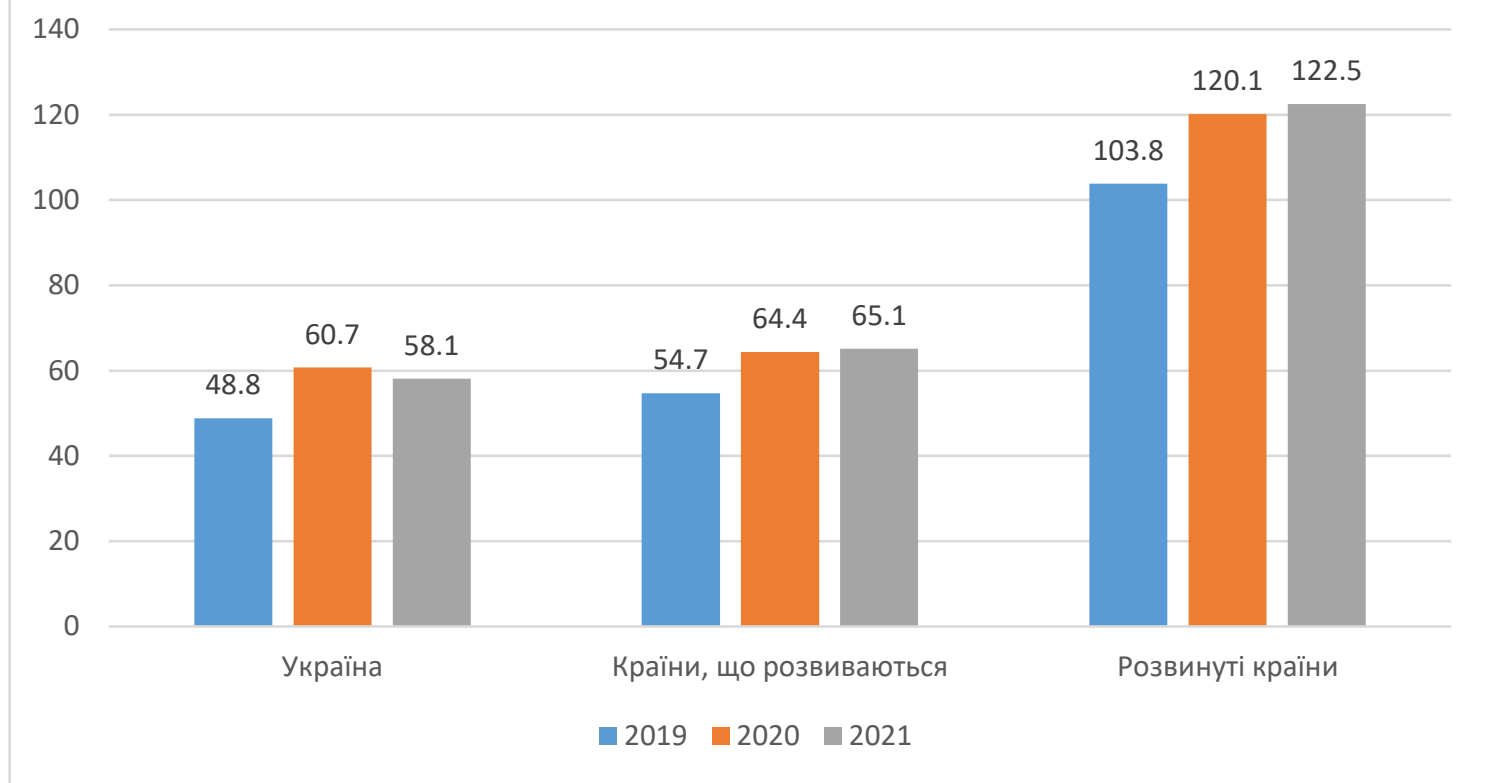

Pис. 5. Державних борг в Україні та різних країнах, у \% до ВВП [16]

Досить показовим $є$ факт, що якщо у розвинених країнах впродовж 2020 року державний борг зріс на $16,3 \%$ ВВП, а в країнах з середніми доходами на 9,7\%, то в Україні показник збільшився на 11,9\%. Збільшення річного приросту державного боргу України у порівнянні із відповідним показником країн, що розвиваються, викликає багато питань до урядовців, які навіть при 1,5-разовому відставанні у вартості фіскального пакету отримали такий показник. Основною причиною такої ситуації є те, що у 2020-2021 роках в Україні було збільшено бюджетні витрати, які пов'язані не 3 антикризової підтримкою. Зокрема, до таких відносилося:

• збільшення видатків на економічну діяльність (збільшення з 3,9\% ВВП у 2019 році до $6,2 \%$ у 2020 -му)

•збільшення видатків на громадський порядок, судову владу та оборону (зростання з 6,3\% ВВП до 6,9\%).

•з іншої сторони, відбулося зростання соціальних видатків на організацію охорони здоров'я (3 3,2\% ВВП до 4,2\%) [16].

Незважаючи на збільшення фінансування сфери охорони здоров'я, даних коштів очевидно було недостатньо для захисту населення під час пандемії, особливо відчутною була потреба у придбанні медичних засобів та обладнання, яке використовувалося для лікування COVID-19.

Таким чином, можна говорити, що фінансова криза створила для діючого уряду можливість розпоряджатися бюджетними коштами на свій розсуд, при цьому деякі із витрат (зокрема фінансування дорожнього будівництва та 
правоохоронних і судових органів) під час кризи COVID-19 складно зачислити до числа адекватних, які б відповідали світовим стандартам виходу із фінансової кризи та були би пов'язані із пандемією.

Відповідно до рекомендацій МВФ, на другій стадії поступового відкриття економіки основними пріоритетами фіскальної політики повинна залишатися сфера охорони здоров'я. Разом з цим потрібно забезпечити ключові програми соціальної підтримки економіки та населення. Ці програми повинні впроваджуватися із врахуванням можливості повторних спалахів інфекції. Вони повинні бути тимчасовими і мати строгий термін, однак у випадку, якщо кризова ситуація повторюватиметься, Міжнародний валютний фонд пропонує державам продовжити програми соціального захисту, забезпечивши їх адресність і можливість охоплення найбільш вразливих верств населення.

На другій стадії поступового відкриття економіки також доцільно активувати державне інвестування та залучати працівників до будівельних робіт за наявності фіскального простору. Україна такого простору не має, а влада при оцінюванні програми Великого будівництва та Реконструкції не ставила за мету залучати до таких робіт українських громадян, які внаслідок скорочення ділової активності стали безробітними. Разом з тим Міжнародний валютний фонд рекомендує переорієнтувати інвестиційні проєкти на вирішення соціальних питань з безробіття.

МВФ передбачена і третя стадія боротьби з пандемією, яка грунтується на тому, що населення країни буде вакцинованим. Разом 3 тим, держави повинні сприяти відновленню економіки, однак не допускати передчасного згортання програм з фіскальної підтримки, оскільки можливі повторні хвилі захворювань навіть після вакцинування, так як сьогодні надавати повну гарантію вирішення проблеми COVID-19 шляхом вакцинування не можуть ні медики, ні статистичні дані.

Країни, які мають незначний фіскальний простір, повинні сфокусуватися на соціальних сферах, малозабезпечених сім'ях і на здійсненні продуктивних державних інвестицій. При визначенні сфер інвестування ключову роль відіграють фізична та цифрова інфраструктура, а також побудова публічної сфери охорони здоров'я.

В моменти вирішення фінансової кризи, доцільно оптимізувати державні видатки та виключити непріоритетні і неефективні з них, до того часу, поки пандемія не буде взята під контроль. 3 метою прискорення розвитку економіки, фіскальна політика повинна забезпечувати адекватне фінансування системи охорони здоров'я, надавати підтримку домогосподарствам та бізнесу, який пережив кризу, однак потребує державної підтримки для відновлення. Основним джерелом фінансування таких потреб може стати тимчасовий податок на відновлення економіки, який міг би стягуватися із підприємств, що отримують високі доходи, або прибуток з накопиченого багатства.

Таким чином, виділимо основні напрями фіскальної політики уряду 3 врахуванням досвіду 2020-2021 рр. та прогнозів щодо розвитку пандемії у світі. 


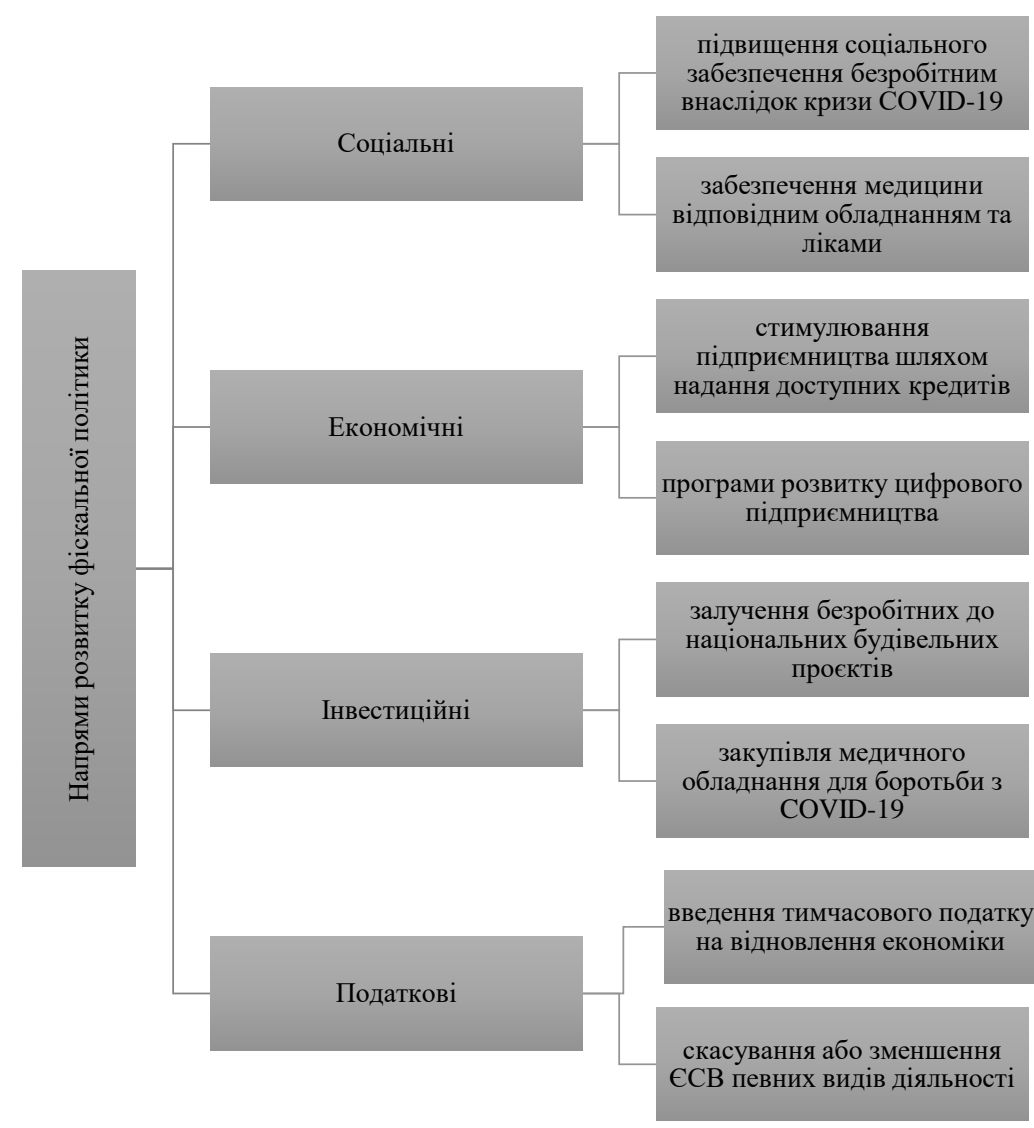

Puc. 6. Напрями розвитку фіскальної політики Уряду на 2022 p.

Після завершення вакцинації у 2022 році у більшості країн світу, у т.ч. в Україні, при досягненні стадії економічного зростання фіскальна політика урядів повинна базуватися на:

•інвестуванні у сфери розвитку людського капіталу з метою підвищення освітнього рівня населення та покращення його здоров'я;

•спрямуванні факторів праці та капіталу на нові галузі економіки, які отримали поштовх для розвитку під час пандемії;

- посиленні системи соціального захисту населення з метою запобігання бідності та зростання нерівності;

•здійсненні податкових реформ, націлених на збільшення оподаткування надприбуткових підприємств та бізнесів.

Висновки та перспективи подальших досліджень. Проблеми у формуванні фіскальної політики по відновленню економіки внаслідок пандемічної кризи виникали практично в кожній країні. Якщо розвинені країни виділяли значні кошти в якості фіскального пакету порятунку, які були спрямовані на додаткові державні видатки або бюджетні кредити, то в Україні зростання витрат на відновлення економіки було практично невідчутним для населення. Враховуючи катастрофічну нестачу коштів на підтримку медицини, незахищених верств населення та економіки, бюджетні кошти розподілялися вкрай нераціонально, зокрема значна частина коштів була 
виділена на розвиток інфраструктури та громадського порядку.

Міжнародні організації, простежуючи за розвитком економік розвинених країн, запропонували свої методи щодо подолання кризи, які повинні базуватися на побудові раціональної фіскальної політики. Здійснивши дослідження у цьому напрямі, можна зробити висновок, що основними напрями розвитку фіскальної політики є соціальні, економічні, інвестиційні та податкові.

Так, незважаючи на проведення вакцинації населення, загроза щодо відновлення кризи не минула, а тому Україна повинна бути готовою до підтримки соціально незахищених верств населення та підприємців, що страждають внаслідок карантинних обмежень. Для значної кількості бізнесу будуть доречними та рятувальними економічні стимули, до яких відноситься надання доступних позик та створення програм розвитку підприємницької діяльності, які могли б працювати та отримувати дохід в умовах карантинних обмежень.

Разом 3 тим політика держави має спрямовуватися не лише на соціальне забезпечення, але й на інвестиційний розвиток. Зокрема, доцільно залучати безробітних людей до різних будівельних проєктів державного значення, а також вкладати кошти в медичне обладнання, що в результаті дозволить підвищити якість медичних послуг та стандарти життя населення.

3 метою зменшення бюджетного дефіциту доцільно переглянути податкову політику щодо підприємств, які отримують великі прибутки і які могли б тимчасово сплачувати податок на відновлення економіки, що формується з високих прибутків або накопичених багатств.

\section{Лimepamypa:}

1. Overview. 2021. THE WORLD BANK. [Електронний ресурс]. - Режим доступу: https://www.worldbank.org/en/country/ukraine/overview

2. Андрущенко В.Л., Тучак, Т.В. Податково-бюджетні заходи протидії пандемії на Заходів. Ефективна економіка. 2020. №5.

3. Fight against COVID-19 and economy: Government action plan released. UKRINFORM. [Електронний ресурс]. - Режим доступу: https://www.ukrinform.net/rubriceconomy/3004619-fight-against-covid19-and-economy-government-action-plan-released.html.

4. Глущенко С. В., Мельник А. І. Фіскальні стимули економічного розвитку у світі в умовах пандемії COVID-19. Наукові записки НАУКМА. 2021. 6 (1).

5. Красота О.В., Яровой А.В. Відновлення макроекономічної стабільності в умовах пандемії COVID-19. Ефективна економіка. 2021. №1.

6. World Economic Outlook, April 2020: Chapter 1. [Електронний ресурс]. - Режим доступу: https://www.imf.org/en/Publications/WEO/Issues/2020/04/14/weo-april-2020.

7. The cut-off date for information in this MPO was March 23, 2020. WORLDBANK. [Електронний ресурс]. - Режим доступу: http://pubdocs.worldbank.org/en/22625149201111 4754/mpo-ukr.pdf.

8. Benmelech E., Tzur-Ilan N. The determinants of fiscal and monetary policies during the COVID-19 crisis. NBER Working Paper 27461. National Bureau of Economic Research. 2020. [Електронний ресурс]. - Режим доступу: https://www.nber.org/system/files/working papers/w27461/w27461.pdf. 
9. Real GDP forecast. 2021. OECD. [Електронний ресурс]. - Режим доступу: https://data.oecd.org/gdp/real-gdp-forecast.htm.

10. ВВП у II кварталі 2021 року. Експрес-випуск. Державна служба статистики України. [Електронний ресурс]. - Режим доступу: http://www.ukrstat.gov.ua/express/ expr2021/09/113.doc.

11. Romer, C. D., and Romer D. H. (2010). The Macroeconomic Effects of Tax Changes: Estimates Based on a New Measure of Fiscal Shocks. American Economic Review, 100 (3), 763-801.

12. Постанова Кабінету Міністрів України No 67. (2021). Про затвердження Порядку надання допомоги по частковому безробіттю. [Електронний ресурс]. - Режим доступу: https://zakon.rada.gov.ua/laws/show/74-2021-\%D0\%BF\#Text

13. Постанова Кабінету Міністрів України № 308. (2020). Про виділення коштів для надання фінансової допомоги Фонду загальнообов'язкового державного соціального страхування на випадок безробіття. [Електронний ресурс]. - Режим доступу: https://zakon.rada.gov.ua/laws/show/308-2020-\%D0\%BF\#Text.

14. Постанова Кабінету Міністрів України No 1040. (2020). Про виділення коштів для надання фінансової допомоги Фонду загальнообов'язкового державного соціального страхування на випадок безробіття для здійснення виплат допомоги по безробіттю та допомоги по частковому безробіттю на період карантину. [Електронний ресурс]. - Режим доступу: https://zakon.rada.gov.ua/laws/show/10402020-\%D0\%BF\#Text

15. Фіскальні пакети порятунку в Україні та групах країн за основними складовими станом на березень 2021p. 2021. GROWFORD. [Електронний ресурс]. - Режим доступу: https://www.growford.org.ua/fiskalni-pakety-poryatunku-v-ukrayini-ta-grupah-krayin-za-osnovnymyskladovymy-stanom-na-berezen-2021r/

16. Державний борг України. 2021. МІНФІН. [Електронний ресурс]. - Режим доступу: https://index.minfin.com.ua/ua/finance/debtgov/

17. Одноразова допомога ФОПам та найманим працівникам. ДІЯ. [Електронний pecypc]. - Режим доступу: https://diia.gov.ua/services/odnorazova-materialna-dopomoga-fopamta-najmanim-pracivnikam

\section{References:}

1. Overview (2021) THE WORLD BANK. Retrieved from https://www.worldbank.org/ en/country/ukraine/overview

2. Andrushchenko V.L., Tuchak, T.V. (2020) Podatkovo-byudzhetni zakhody protydiyi pandemiyi na Zakhodi [Fiscal measures to counter the pandemic in the West]. Efficient economy, 5.

3. Fight against COVID-19 and economy: Government action plan released. UKRINFORM. Retrieved from https://www.ukrinform.net/rubric-economy/3004619-fight-againstcovid19-and-economy-government-action-plan-released.html

4. Hlushchenko S. V., Mel'nyk A. I. (2021). Fiskalni stymuly ekonomichnoho rozvytku u sviti v umovakh pandemiyi COVID-19 [Fiscal incentives for economic development in the world in the context of the COVID-19 pandemic]. Scientific notes of NAUKMA, 6 (1).

5. Krasota O.V., Yarovoy A.V. (2021) Vidnovlennya makroekonomichnoyi stabilnosti v umovakh pandemiyi COVID-19 [Restoration of macroeconomic stability in the context of the COVID-19 pandemic]. Efficient economy, №1.

6. World Economic Outlook, April 2020: Chapter 1. Retrieved from https://www.imf.org/en/Publications/WEO/Issues/2020/04/14/weo-april-2020.

7. The cut-off date for information in this MPO was March 23, 2020. WORLDBANK. Retrieved from http://pubdocs.worldbank.org/en/226251492011114754/mpo-ukr.pdf.

8. Benmelech E., Tzur-Ilan N. (2020). The determinants of fiscal and monetary policies during the COVID-19 crisis. NBER Working Paper 27461. National Bureau of Economic Research. Retrieved from https://www.nber.org/system/files/working_papers/w27461/w27461.pdf. 
9. Real GDP forecast (2021) OECD. Retrieved from https://data.oecd.org/gdp/real-gdpforecast.htm.

10. GDP in the second quarter of 2021. Express issue. State Statistics Service of Ukraine. Retrieved from http://www.ukrstat.gov.ua/express/expr2021/09/113.doc [in Ukrainian].

11. Romer, C. D., and Romer D. H. (2010). The Macroeconomic Effects of Tax Changes: Estimates Based on a New Measure of Fiscal Shocks. American Economic Review, 100 (3), 763-801.

12. Pro zatverdzhennya Poryadku nadannya dopomohy po chastkovomu bezrobittyu. Postanova Kabinetu Ministriv Ukraïny No 67. 2021. Retrieved from https://zakon.rada.gov.ua/laws/show/74-2021-\%D0\%BF\#Text [in Ukrainian].

13. Pro vydilennya koshtiv dlya nadannya finansovoï dopomohy Fondu zahalnoobovyazkovoho derzhavnoho sotsialnoho strakhuvannya na vypadok bezrobittya. Postanova Kabinetu Ministriv Ukrajiny No 308. 2020. Retrieved from https://zakon.rada.gov.ua/laws/show/308-2020-\%D0\%BF\#Text [in Ukrainian].

14. Pro vydilennya koshtiv dlya nadannya finansovoï dopomohy Fondu zahalnoobovyazkovoho derzhavnoho sotsialnoho strakhuvannya na vypadok bezrobittya dlya zdijsnennya vyplat dopomohy po bezrobittyu ta dopomohy po chastkovomu bezrobittyu na period karantynu. Postanova Kabinetu Ministriv Ukrajiny No 1040. 2020. Retrieved from https://zakon.rada.gov.ua/laws/show/10402020-\%D0\%BF\#Text [in Ukrainian].

15. Fiscal rescue packages in Ukraine and groups of countries by main components as of March 2021. (2021). GROWFORD. Retrieved from https://www.growford.org.ua/fiskalni-paketyporyatunku-v-ukrayini-ta-grupah-krayin-za-osnovnymy-skladovymy-stanom-na-berezen-2021r/

16. Public debt of Ukraine (2021) MINFIN. Retrieved from https://index.minfin.com.ua/ ua/finance/debtgov/ [in Ukrainian].

17. One-time assistance to sole proprietors and employees. ACTION. Retrieved from https: // diia.gov.ua/services/odnorazova-materialna-dopomoga-fopam-ta-najmanim-pracivnikam [in Ukrainian]. 